\title{
PEMODELAN MATEMATIKA ALIRAN UDARA PADA BRONKUS AKIBAT PENYAKIT BRONKITIS KRONIS
}

\author{
Devi Permatasari ${ }^{1}$, Arif Fatahillah ${ }^{2}$, Susi Setiawani ${ }^{2}$ \\ Program Studi Pendidikan Matematika, FKIP, Universitas Jember \\ Jalan Kalimantan 37 Kampus Tegalboto Jember 68121 \\ E-mail: devi25permatasari@gmail.com
}

\begin{abstract}
Chronic bronchitis is a disease that attacks the respiratory tract and is one of the dangerous diseases that can cause death in the world. This study builds a mathematical model of airflow velocity in the bronchi due to chronic bronchitis which is influenced by mucus thickness and initial velocity. The type of research used is simulation research to find a picture of a simple system that will be manipulated or controlled to get an effect similar to the actual situation. The mathematical model is built on the reduction of the momentum equation and the mass continuity equation which is solved using the finite volume method and the QUICK discretization technique. The volume method is used because the fluid flow studied is $\mathrm{O}_{2}$ gas which is classified as unstructured. So by using the volume method, it will be easier to discretize to determine the values that will be sought in the discretization process.
\end{abstract}

Keywords: Chronic bronchitis, Finite Volume Method, Mathematical Modeling.

\section{PENDAHULUAN}

Matematika merupakan ilmu yang menjadi dasar dan memiliki peranan penting dalam perkembangan ilmu pengetahuan serta teknologi modern. Matematika juga digunakan dalam berbagai disiplin ilmu diantaranya ilmu alam, ilmu ekonomi, dan ilmu kedokteran. Cabang matematika dalam disiplin ilmu kedokteran yaitu matematika terapan yang digunakan untuk mengaplikasikan matematika guna memecahkan suatu masalah yang konkret pada berbagai disiplin ilmu yang salah satunya adalah kedokteran. Pada akhir 2019 wabah yang berasal dari Wuhan, provinsi Hubei, Cina, sebagai publik darurat kesehatan internasional keprihatinan pada 30 Januari 2020, oleh WHO [11]. Penyakit akibat wabah ini

\footnotetext{
${ }^{1}$ Mahasiswa S-1 Prodi Pendidikan Matematika FKIP Universitas Jember

${ }^{2}$ Dosen Prodi Pendidikan Matematika FKIP Universitas Jember
} 
secara resmi dinamai Coronavirus Disease-2019 (Covid-19, oleh WHO pada 11 Februari 2020). Covid-19 juga disebut sebagai Pneumonia Parah dengan novel Patogen pada 15 Januari 2019 oleh CDC Taiwan, Departemen Kesehatan dan dapat dilaporkan menjadi salah satu penyakit menular. Wabah penyakit Covid-19 yang sedang berlangsung saat ini terjadi di Cina menyebar dengan cepat secara global [12]. Covid-19 merupakan penyakit yang disebabkan oleh virus, dimana virus ini akan menyebabkan gangguan pernafasan pada penderitanya. Secara medis, gejala Covid-19 terlihat dari timbulnya infeksi seperti demam, batuk, sesak napas, dan kesulitan bernapas. Pada kondisi awal infeksi, Covid-19 menyerang sel paru-paru manusia secara cepat. Ada dua tipe sel yang diserang, yaitu sel yang menghasilkan mukus (lendir) dan sel dengan silia (memiliki struktur seperti rambut). Covid-19 menginfeksi dan membunuh sel silia, yang kemudian mengelupas dan mengisi saluran udara pasien dengan puing-puing sisa sel atau jaringan dan cairan sehingga membuat tidak optimalnya kerja organ. Selain Covid-19, penyakit lain yang menyebabkan gangguan pernafasan adalah bronkitis. Menurut WHO (World Health Organization) dalam World Health Report 2000 pada saat ini, penyakit bronkitis diderita oleh sekitar 64 juta orang di dunia. Faktor utamanya yaitu merokok, virus,bakteri, polusi udara dalam ruangan/luar ruangan serta bahan kimia. Di Amerika Serikat yang terinfeksi bronkitis kronis berkisar 4,45\% atau 12,1 juta jiwa dari populasi perkiraan yang digunakan 293 juta jiwa. Selanjutnya Thailand merupakan salah satu negara yang tingkat prevalensi bronkitis kronisnya paling tinggi di ASEAN yaitu berkisar 2.885.561 jiwa dari populasi perkiraan yang digunakan sebesar 64.865.523 jiwa [10]. SKRT 2001, asma, bronkitis kronis dan emfisema mendudukiperingkat ke-3 (PMR 12,7\%) sebagai penyebab angka kesakitan umum di Indonesia setelah sistem sirkulasi, infeksi, dan parasite. Penderita penyakit bronkitis kronis di Indonesia sebanyak 1,6 juta jiwa [9].

Bronkitis adalah istilah umum untuk terjadinya infeksi yang menyebabkan iritasi dan peradangan pada area bronkus di paru-paru. Ada 2 jenis bronkitis yaitu bronkitis akut dan kronis [3]. Bronkitis kronis adalah bentuk peradangan yang lama dan berkesinambungan akibat serangan berulang bronkitis akut atau 
penyakit-penyakit umum kronis, dan ditandai dengan batuk, ekspektorasi, dan perubahan sekunder jaringan paru. Bronkitis kronis disebabkan karena adanya penebalan dinding bronkus akibat inflamasi sehingga proses bernafas akan terganggu dan ini menjadi salah satu faktor yang menyebabkan sesak nafas. Penumpukan mukus pada ruang bronkus dan paru-paru akibat proses inflamasi mengganggu jalan masuk oksigen ke dalam tubuh. Penderita biasanya mempunyai riwayat merokok dan sering mengalami infeksi pernapasan. Tanda dan gejala dari bronkitis kronis diawali dengan manifestasi infeksi saluran pernafasan atas seperti hidung berair, tidak enak badan, menggigil, pegal-pegal, sakit kepala, dan tenggorokan sakit. Tanda utama penyakit bronkitis kronis adalah batuk. Batuk yang terjadi bisa ringan atau berat dengan dahak yang purulent. Penderita penyakit bronkitis kronis biasanya akan terbatuk pada pagi hari untuk mengeluarkan dahak dalam jumlah banyak. Dahak umumnya berwarna putih atau kuning dan liat [5].

Saat ini hampir semua disiplin ilmu memanfaatkan model matematika seperti fisika, biologi, kedokteran, ilmu sosial dan politik, ekonomi, dan teknik. Model matematika adalah suatu model representasi dari sistem nyata yang dijabarkan dalam bentuk simbol dan pernyataan matematika[8]. Aplikasi model matematika pada bidang kedokteran terdapat pada penelitian yang telah dilakukan oleh Kori et al. [6] yang berjudul "Numerical Simulation of Mucus Clearance Inside Lung Airways" mensimulasikan tentang perilaku aliran fluida dimana dinding pada saluran udara paru-parunya. Hasil yang didapat menunjukkan bahwa kecepatan aliran fluida pada saluran udara paru-paru akibat mengalami peningkatan seiring dengan meningkatnya frekuensi pernafasan. Penelitian relevan yang dilakukan oleh Putra yang berjudul "Analisis numerik aliran darah pada penyempitan pembuluh darah arteri menggunakan metode volume hingga" [4] mengenai ketebalan bercak gumpalan lemak didapatkan hasil bahwa semakin tebal bercak gumpalan lemak maka peningkatan kecepatan aliran darah juga semakin besar. Sementara pada penelitian yang dilakukan oleh Jong et al. yang berjudul "Aging effects on airflow dynamics and lung function in human" [7] didapatkan hasil hambatan yang terdapat pada bronkus dapat menyebabkan 
diameter bronkus menjadi lebih kecil dari yang semestinya dapat mengakibatkan kecepatan aliran udaranya semakin besar. Model matematika yang dibentuk pada penelitian ini memodifikasi dari penelitian yang dilakukan oleh Kori et al. dan Putra. Model matematika pada penelitian ini dipengaruhi oleh ketebalan mukus dan kecepatan awal kemudian diselesaikan menggunakan metode volume hingga.

Model matematika yang digunakan diselesaikan menggunakan metode volume hingga. Metode volume hingga adalah metode yang digunakan untuk menyelesaikan permasalahan pada model matematika dengan suatu titik diskrit yang kontinu dan jarak antara titik tersebut teratur membentuk suatu grid atau mesh. Metode volume hingga dapat digunakan pada bentuk benda yang tidak teratur seperti gas. Pada penelitian ini, aliran fluida yang diteliti adalah gas $\mathrm{O}_{2}$ yang tergolong tidak terstruktur. Sehingga dengan menggunakan metode volume hingga akan bisa lebih mudah dalam melakukan diskritisasi ntuk menentukan nilai-nilai yang akan di cari pada proses diskritisasi. Hal ini sesuai dengan penelitian Ali yang menyebutkan bahwa benda yang tidak terstruktur dapat didiskritisasi dengan mudah menggunakan metode volume hingga. Metode ini juga sering digunakan karena metode ini memiliki ketelitian yang tinggi dan bisa digunakan untuk semua kasus aliran fluida [2]. Metode ini dapat diselesaikan secara numerik menggunakan software MATLAB.

Berdasarkan uraian di atas, maka tujuan penelitian ini membentuk dan mengembangkan model matematika kecepatan aliran udara pada bronkus akibat penyakit bronkitis kronis, menganalisis pengaruh variabel yang berbeda dari penelitian sebelumnya yaitu pengaruh ketebalan mukus dan kecepatan awal yang berbeda-beda. Penyelesaian persamaan matematika diharapkan lebih mudah dan solusi yang diperoleh mendekati nilai sebenarnya [1]. Model matematika diselesaikan menggunakan metode volume hingga dan di diskritisasi QUICK.

\section{METODE PENELITIAN}

Penelitian ini merupakan jenis penelitian simulasi. Penelitian simulasi merupakan jenis penelitian yang dilakukan untuk mengetahui gambaran dari suatu sistem dengan sederhana yang akan diterapkan manipulasi atau pengendalian 
untuk mendapatkan pengaruh yang mirip dengan keadaan sebenarnya. Pada penelitian ini, memodelkan matematika dan mensimulasikan aliran udara pada bronkus akibat penyakit bronkitis kronis yang dipengaruhi oleh ketebalan mukus dan kecepatan awal. Penyelesaian model matematika dengan menggunakan metode volume hingga sampai didapatkan hasil atau data-data yang diperoleh mendekati keadaan sebenarnya.

\section{HASIL PENELITIAN}

Analisis model matematika kecepatan aliran udara pada bronkus akibat penyakit bronkitis kronis dilakukan dengan beberapa tahapan. Tahap pertama yaitu pembentukan model matematika kecepatan aliran udara pada bronkus didasarkan pada persamaan momentum dan persamaan kontinuitas massa. Persamaan momentum merupakan bentuk persamaan diferensial yang menghubungkan gaya-gaya yang bekerja pada volume kendali, yaitu tekanan $(P)$, gaya tarik $(b)$, gaya gravitasi $(g)$ dan stokes $\left(k_{f}\right)$. Berikut merupakan skema kendali persamaan momentum aliran udara pada bronkus akibat penyakit bronkitis kronis.

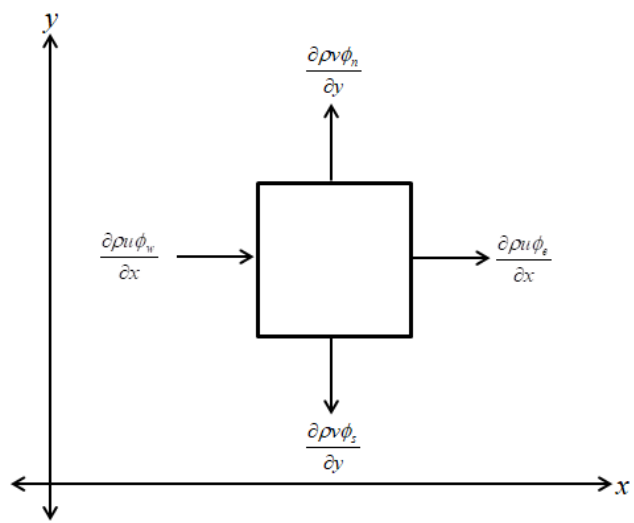

Gambar 1. Skema Kendali Persamaan Momentum

Maka persamaan momentum yang diperoleh sebagai berikut.

$$
\begin{gathered}
\frac{\partial \rho \phi_{0}}{\partial t}+[\text { purerate }]=\sum F \\
\frac{\partial \rho \phi_{0}}{\partial t}+[\text { out }- \text { in }]=\sum F
\end{gathered}
$$




$$
\begin{aligned}
& \frac{\partial \rho \phi_{0}}{\partial t}+\left[\left(\frac{\partial \rho \phi_{e}}{\partial x}-\frac{\partial \rho \phi_{w}}{\partial x}\right)+\left(\frac{\partial \rho \phi_{n}}{\partial y}-\frac{\partial \rho \phi_{s}}{\partial y}\right)\right]=-\varepsilon \frac{\partial P}{\partial x}-\varepsilon \frac{\partial P}{\partial y}+u\left(\frac{\partial^{2} \phi_{0}}{\partial x^{2}}+\left(\frac{1}{x}\right) \frac{\partial \phi_{0}}{\partial x}+\frac{\partial^{2} \phi_{0}}{\partial y^{2}}\right)+ \\
& \left(-\frac{\varepsilon v}{K} u_{x}+k_{f} \frac{\rho p}{\rho a}\left(v_{x}-u_{x}\right)-\frac{\varepsilon b}{K} u_{x}^{2}\right)+g_{x}\left(\frac{\rho_{p}-\rho_{a}}{\rho_{p}}\right)+v\left(\frac{\partial^{2} \phi_{0}}{\partial x^{2}}+\left(\frac{1}{x}\right) \frac{\partial \phi_{0}}{\partial x}+\frac{\partial^{2} \phi_{0}}{\partial y^{2}}\right)+\left(-\frac{\varepsilon v}{K} u_{y}+\right. \\
& \left.k_{f} \frac{\rho p}{\rho a}\left(v_{y}-u_{y}\right)-\frac{\varepsilon b}{K} u_{y}^{2}\right)+g_{y}\left(\frac{\rho_{p}-\rho_{a}}{\rho_{p}}\right)+R(z)
\end{aligned}
$$

dengan,

$$
R(z)=R_{0}-\frac{\delta_{s}}{2}\left(1+\cos \frac{2 \pi}{L o}\left(z-d-\frac{L o}{2}\right)\right)
$$

Selain menggunakan persamaan momentum, penelitian ini juga menggunakan persamaan kontinuitas massa berdasarkan hukum kekekalan massa.

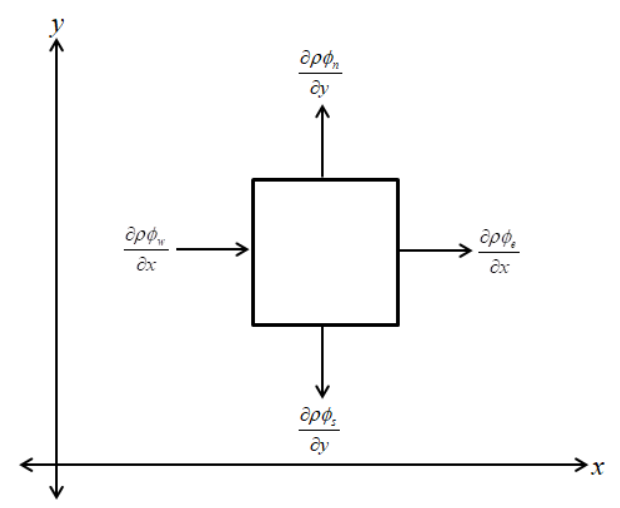

Gambar 2. Skema Kendali Persamaan Kontinuitas Massa

Dari skema kendali persamaan kontinuitas massa diatas maka persamaan kontinuitas massa yang diperoleh sebagai berikut.

$$
\begin{aligned}
& \frac{\partial \rho \phi_{0}}{\partial t}+[\text { purerate }]=\text { Source } \\
& \frac{\partial \rho \phi_{0}}{\partial t}+[\text { out }- \text { in }]=0 \\
& \frac{\partial \rho \phi_{0}}{\partial t}+\left[\left(\frac{\partial \rho \phi_{e}}{\partial x}-\frac{\partial \rho \phi_{w}}{\partial x}\right)+\left(\frac{\partial \rho \phi_{n}}{\partial y}-\frac{\partial \rho \phi_{s}}{\partial y}\right)\right]=0
\end{aligned}
$$

Penyelesaian model matematika menggunakan metode volume hingga dengan mengintegralkan persamaan momentum dan persamaan kontinuitas massa terhadap tiga variabel yaitu $x, y$ dan $t$. Berikut merupakan bentuk integral dari persamaan momentum. 


$$
\begin{aligned}
& \int_{t}^{t+\Delta t} \int_{y}^{y+\Delta y} \int_{x}^{x+\Delta x}\left[\frac{\partial \rho \phi_{0}}{\partial t}+\left(\frac{\partial \rho u \phi_{e}}{\partial x}-\frac{\partial \rho u \phi_{w}}{\partial x}\right)+\left(\frac{\partial \rho v \phi_{n}}{\partial y}-\frac{\partial \rho v \phi_{s}}{\partial y}\right)\right] d x d y d t=\int_{t}^{t+\Delta t} \int_{y}^{y+\Delta y} \int_{x}^{x+\Delta x}\left[-\varepsilon \frac{\partial P}{\partial x}-\varepsilon \frac{\partial P}{\partial y}+\right. \\
& u\left(\frac{\partial^{2} \phi_{0}}{\partial x^{2}}+\left(\frac{1}{x}\right) \frac{\partial \phi_{0}}{\partial x}+\frac{\partial^{2} \phi_{0}}{\partial y^{2}}\right)+\left(-\frac{\varepsilon v}{K} u_{x}+k_{f} \frac{\rho p}{\rho a}\left(v_{x}-u_{x}\right)-\frac{\varepsilon b}{K} u_{x}^{2}\right)+g_{x}\left(\frac{\rho_{p}-\rho_{a}}{\rho_{p}}\right)+v\left(\frac{\partial^{2} \phi_{0}}{\partial x^{2}}+\left(\frac{1}{x}\right)\right. \\
& \left.\left.\frac{\partial \phi_{0}}{\partial x}+\frac{\partial^{2} \phi_{0}}{\partial y^{2}}\right)+\left(-\frac{\varepsilon v}{K} u_{y}+k_{f} \frac{\rho p}{\rho a}\left(v_{y}-u_{y}\right)-\frac{\varepsilon b}{K} u_{y}^{2}\right)+g_{y}\left(\frac{\rho_{p}-\rho_{a}}{\rho_{p}}\right)+R(z)\right] d x d y d t
\end{aligned}
$$

Hasil dari persamaan setelah diintegralkan sebagai berikut.

$$
\begin{aligned}
& \rho \phi_{0} \Delta x \Delta y+\rho u \phi_{e} \Delta y \Delta t-\rho u \phi_{w} \Delta y \Delta t+\rho v \phi_{n} \Delta x \Delta t-\rho v \phi_{s} \Delta x \Delta t=-\varepsilon P \Delta y \Delta t-\varepsilon P \Delta x \Delta t+ \\
& u\left(\phi_{0} \frac{\Delta y \Delta t}{\Delta x}+\frac{1}{x} \phi_{0} \Delta y \Delta t+\phi_{0} \frac{\Delta x \Delta t}{\Delta y}\right)-\frac{\varepsilon v}{K} u_{x} \Delta x \Delta y \Delta t+k_{f} \frac{\rho p}{\rho a}\left(v_{x}-u_{x}\right) \Delta x \Delta y \Delta t-\frac{\varepsilon b}{K} u_{x}{ }^{2} \\
& \Delta x \Delta y \Delta t+g_{x}\left(\frac{\rho_{p}-\rho_{a}}{\rho_{p}}\right) \Delta x \Delta y \Delta t+v\left(\phi_{0} \frac{\Delta y \Delta t}{\Delta x}+\frac{1}{x} \phi_{0} \Delta y \Delta t+\phi_{0} \frac{\Delta x \Delta t}{\Delta y}\right)-\frac{\varepsilon v}{K} u_{y} \Delta x \Delta y \\
& \Delta t+k_{f} \frac{\rho p}{\rho a}\left(v_{y}-u_{y}\right) \Delta x \Delta y \Delta t-\frac{\varepsilon b}{K} u_{y}{ }^{2} \Delta x \Delta y \Delta t+g_{y}\left(\frac{\rho_{p}-\rho_{a}}{\rho_{p}}\right) \Delta x \Delta y \Delta t+R(z) \Delta x \Delta y \Delta t
\end{aligned}
$$

Persamaan (8) dapat disederhanakan menjadi,

$$
\begin{aligned}
& \phi_{0} \rho \Delta x \Delta y-u v\left(\frac{\Delta y \Delta t}{\Delta x}+\frac{1}{x} \phi_{0} \Delta y \Delta t+\phi_{0} \frac{\Delta x \Delta t}{\Delta y}\right)+\rho u\left(\phi_{e} \Delta y \Delta t-\phi_{w} \Delta y \Delta t\right)+\rho v\left(\phi_{n} \Delta x \Delta t-\right. \\
& \left.\phi_{s} \Delta x \Delta t\right)=-\varepsilon P \Delta t(\Delta t+\Delta x)-\left(u_{x}+u_{y}\right) \frac{\varepsilon v}{K} \Delta x \Delta y \Delta t+\left(\left(v_{x}-u_{x}\right)+\left(v_{y}-u_{y}\right)\right) k_{f} \frac{\rho p}{\rho a} \Delta x \Delta y \\
& \Delta t-\left(u_{x}{ }^{2}+u_{y}{ }^{2}\right) \frac{\varepsilon b}{K} \Delta x \Delta y \Delta t+\left(g_{x}+g_{y}\right) \frac{\rho_{p}-\rho_{a}}{\rho_{p}} \Delta x \Delta y \Delta t+R(z) \Delta x \Delta y \Delta t
\end{aligned}
$$

dengan,

$$
R(z)=R_{0}-\frac{\delta_{s}}{2}\left(1+\cos \frac{2 \pi}{L o}\left(z-d-\frac{L o}{2}\right)\right)
$$

Selanjutnya pengintegralan persamaan kontinuitas massa terhadap tiga variabel yaitu $x, y$ dan $t$.

$$
\int_{t}^{t+\Delta t} \int_{y}^{y+\Delta y} \int_{x}^{x+\Delta x}\left[\frac{\partial \rho \phi_{0}}{\partial t}+\left(\frac{\partial \rho \phi_{e}}{\partial x}-\frac{\partial \rho \phi_{w}}{\partial x}\right)+\left(\frac{\partial \rho \phi_{n}}{\partial y}-\frac{\partial \rho \phi_{s}}{\partial y}\right)\right] d x d y d t=\int_{t}^{t+\Delta t} \int_{y}^{y+\Delta y} \int_{x}^{x+\Delta x} 0 d x d y d t(10)
$$

Hasil dari persamaan setelah diintegralkan sebagai berikut.

$$
\begin{aligned}
& \rho \phi_{0} \Delta x \Delta y+\rho \phi_{e} \Delta y \Delta t-\rho \phi_{w} \Delta y \Delta t+\rho \phi_{n} \Delta x \Delta t-\rho \phi_{s} \Delta x \Delta t=0 \\
& \phi_{0}=\left(\phi_{w}-\phi_{e}\right) \frac{\Delta t}{\Delta x}+\left(\phi_{s}-\phi_{n}\right) \frac{\Delta t}{\Delta y}
\end{aligned}
$$


Setelah didapatkan hasil integral pada masing-masing persamaan, kemudian persamaan-persamaan tersebut disubstitusikan satu dengan yang lain sebagai berikut.

$$
\begin{aligned}
& \phi_{w}\left[(\rho-\rho u) \Delta y \Delta t-u v\left(\frac{\Delta y(\Delta t)^{2}}{(\Delta x)^{2}}+\frac{1}{x} \frac{\Delta y(\Delta t)^{2}}{\Delta x}+\frac{(\Delta t)^{2}}{\Delta y}\right)\right]+\phi_{e}[-(\rho-\rho u) \Delta y \Delta t+ \\
& \left.u v\left(\frac{\Delta y(\Delta t)^{2}}{(\Delta x)^{2}}+\frac{1}{x} \frac{\Delta y(\Delta t)^{2}}{\Delta x}+\frac{(\Delta t)^{2}}{\Delta y}\right)\right]+\phi_{s}\left[(\rho-\rho v) \Delta x \Delta t-u v\left(\frac{(\Delta t)^{2}}{\Delta x}+\frac{1}{x}(\Delta t)^{2}+\right.\right. \\
& \left.\left.\frac{\Delta x(\Delta t)^{2}}{(\Delta y)^{2}}\right)\right]+\phi_{n}\left[-(\rho-\rho v) \Delta x \Delta t+u v\left(\frac{(\Delta t)^{2}}{\Delta x}+\frac{1}{x}(\Delta t)^{2}+\frac{\Delta x(\Delta t)^{2}}{(\Delta y)^{2}}\right)\right]=-\varepsilon p \Delta t \\
& (\Delta y+\Delta x)-\varepsilon p \Delta t(\Delta y+\Delta x)-\left(u_{x}+u_{y}\right) \frac{\varepsilon v}{K} \Delta x \Delta y \Delta t+\left(\left(v_{x}-u_{x}\right)+\left(v_{y}-u_{y}\right)\right) K_{f} \frac{\rho_{p}}{\rho_{a}} \\
& \Delta x \Delta y \Delta t-\left(u_{x}{ }^{2}+u_{y}{ }^{2}\right) \frac{\varepsilon b}{K} \Delta x \Delta y \Delta t+\left(g_{x}+g_{y}\right) \frac{\rho_{p}-\rho_{a}}{\rho_{p}} \Delta x \Delta y \Delta t+R(z) \Delta x \Delta y \Delta t
\end{aligned}
$$
dengan,

$$
R(z)=R_{0}-\frac{\delta_{s}}{2}\left(1+\cos \frac{2 \pi}{L o}\left(z-d-\frac{L o}{2}\right)\right)
$$

Setelah mensubtitusikan masing-masing persamaan kemudian mensubtitusikan nilai besaran fisika yang paling umum pada Persamaan 13 seperti pada Tabel 1, sehingga diperoleh persamaan akhir.

Tabel 1. Besaran Fisika

\begin{tabular}{|c|c|c|l|}
\hline No & Simbol & Nilai & \multicolumn{1}{|c|}{ Keterangan } \\
\hline 1 & $g_{x}$ & $9,8 \mathrm{~m} / \mathrm{s}^{2}$ & Gaya gravitasi terhadap sumbu- $x$ \\
\hline 2 & $g_{y}$ & $9,8 \mathrm{~m} / \mathrm{s}^{2}$ & Gaya gravitasi terhadap sumbu- $y$ \\
\hline 3 & $\rho$ & $1,2 \mathrm{~kg} / \mathrm{m}^{3}$ & Massa jenis udara \\
\hline 4 & $\rho_{p}$ & $1000 \mathrm{~kg} / \mathrm{m}^{3}$ & Massa jenis partikel \\
\hline
\end{tabular}

$\phi_{w}\left[(\rho-\rho u) \Delta y \Delta t-u v\left(\frac{\Delta y(\Delta t)^{2}}{(\Delta x)^{2}}+\frac{1}{x} \frac{\Delta y(\Delta t)^{2}}{\Delta x}+\frac{(\Delta t)^{2}}{\Delta y}\right)\right]+\phi_{e}[-(\rho-\rho u) \Delta y \Delta t+$ $\left.u v\left(\frac{\Delta y(\Delta t)^{2}}{(\Delta x)^{2}}+\frac{1}{x} \frac{\Delta y(\Delta t)^{2}}{\Delta x}+\frac{(\Delta t)^{2}}{\Delta y}\right)\right]+\phi_{s}\left[(\rho-\rho v) \Delta x \Delta t-u v\left(\frac{(\Delta t)^{2}}{\Delta x}+\frac{1}{x}(\Delta t)^{2}+\right.\right.$ 


$$
\begin{aligned}
& \left.\left.\frac{\Delta x(\Delta t)^{2}}{(\Delta y)^{2}}\right)\right]+\phi_{n}\left[-(\rho-\rho v) \Delta x \Delta t+u v\left(\frac{(\Delta t)^{2}}{\Delta x}+\frac{1}{x}(\Delta t)^{2}+\frac{\Delta x(\Delta t)^{2}}{(\Delta y)^{2}}\right)\right]=-\varepsilon p \Delta t \\
& (\Delta y+\Delta x)-\varepsilon p \Delta t(\Delta y+\Delta x)-\left(u_{x}+u_{y}\right) \frac{\varepsilon v}{K} \Delta x \Delta y \Delta t+\left(\left(v_{x}-u_{x}\right)+\left(v_{y}-u_{y}\right)\right) 833,33 K_{f} \\
& \Delta x \Delta y \Delta t-\left(u_{x}{ }^{2}+u_{y}{ }^{2}\right) \frac{\varepsilon b}{K} \Delta x \Delta y \Delta t+19,58 \Delta x \Delta y \Delta t+R(z) \Delta x \Delta y \Delta t
\end{aligned}
$$

dengan,

$$
R(z)=R_{0}-\frac{\delta_{s}}{2}\left(1+\cos \frac{2 \pi}{L o}\left(z-d-\frac{L o}{2}\right)\right)
$$

\section{KESIMPULAN}

Model matematika aliran udara pada bronkus akibat penyakit bronkitis kronis diperoleh dari persamaan momentum dan kontinuitas massa. Berdasakan hasil penelitian diperoleh pengembangan model matematika aliran udara pada bronkus akibat penyakit bronkitis sebagai berikut.

$$
\begin{aligned}
& \phi_{w}\left[(\rho-\rho u) \Delta y \Delta t-u v\left(\frac{\Delta y(\Delta t)^{2}}{(\Delta x)^{2}}+\frac{1}{x} \frac{\Delta y(\Delta t)^{2}}{\Delta x}+\frac{(\Delta t)^{2}}{\Delta y}\right)\right]+\phi_{e}[-(\rho-\rho u) \Delta y \Delta t+ \\
& \left.u v\left(\frac{\Delta y(\Delta t)^{2}}{(\Delta x)^{2}}+\frac{1}{x} \frac{\Delta y(\Delta t)^{2}}{\Delta x}+\frac{(\Delta t)^{2}}{\Delta y}\right)\right]+\phi_{s}\left[(\rho-\rho v) \Delta x \Delta t-u v\left(\frac{(\Delta t)^{2}}{\Delta x}+\frac{1}{x}(\Delta t)^{2}+\right.\right. \\
& \left.\left.\frac{\Delta x(\Delta t)^{2}}{(\Delta y)^{2}}\right)\right]+\phi_{n}\left[-(\rho-\rho v) \Delta x \Delta t+u v\left(\frac{(\Delta t)^{2}}{\Delta x}+\frac{1}{x}(\Delta t)^{2}+\frac{\Delta x(\Delta t)^{2}}{(\Delta y)^{2}}\right)\right]=-\varepsilon p \Delta t \\
& (\Delta y+\Delta x)-\varepsilon p \Delta t(\Delta y+\Delta x)-\left(u_{x}+u_{y}\right) \frac{\varepsilon v}{K} \Delta x \Delta y \Delta t+\left(\left(v_{x}-u_{x}\right)+\left(v_{y}-u_{y}\right)\right) 833,33 K_{f} \\
& \Delta x \Delta y \Delta t-\left(u_{x}{ }^{2}+u_{y}{ }^{2}\right) \frac{\varepsilon b}{K} \Delta x \Delta y \Delta t+19,58 \Delta x \Delta y \Delta t+R(z) \Delta x \Delta y \Delta t
\end{aligned}
$$

dengan,

$$
R(z)=R_{0}-\frac{\delta_{s}}{2}\left(1+\cos \frac{2 \pi}{L o}\left(z-d-\frac{L o}{2}\right)\right)
$$

Hasil pengembangan model matematika diperoleh berdasarkan faktor-faktor yang mempengaruhi aliran udara pada bronkus. Model matematika dapat disimulasikan untuk memperoleh hasil numerik yang dapat dibandingkan dengan 
kondisi sebenarnya, sehingga peneliti lain dapat melakukan simulasi model matematika yang diperoleh.

\section{DAFTAR PUSTAKA}

[1] A. Fatahillah, Dafik, and J. Susanto, "Analisis Kecepatan Aliran Udara pada Gedung Bertingkat Karena Pengaruh Penghalang di Depannya," Kadikma, vol. 6, no. 2, pp. 75-82, 2015.

[2] A. Fatahillah, T. B. Setiawan, and M. A. Masyhudi, "Pemodelan Matematika Penyebaran Polutan Udara di Kawasan PLTU Menggunakan Metode Volume Hingga," Kadikma, vol.9, no 3, pp. 194-203, 2019.

[3] A. Muttaqin, Asuhan Keperawatan Klien dengan Gangguan Sistem Persarafan, Salemba Medika, 2008.

[4] A. S. H. Putra, Suharto, and A. Fatahillah, "Analisis Sirkulasi Udara pada Sistem Pernafasan Manusia menggunakan Metode Volume Hingga," Kadikma, vol. 8, no. 2, pp. 95-104, 2017.

[5] Ikawati and Zulies, Farmakoterapi Penyakit Sistem Pernafasan, Pustaka Adipura, 2007.

[6] J. Kori and Pratibha, "Numerical Simulation of Mucus Clearance Inside Lung Airways," Journal of Applied Fluid Mechanics, vol. 5, no. 11, pp. 1163-1171, 2018.

[7] J. W. Kim, R. L. Helse, A. M. Reynolds, and R. M. Pidaparti, "Aging effects on airflow dynamics andlung function in human bronchioles," PLoS $O N E$, vol. 12 , no. $8,2017.7$

[8] J. Z. Liang and F. H. Li, "Simulation of heat transfer in hollow glass bead filled polypropylene composites by finite element method," Polymer Testing, vol. 26, no. 3, pp. 419-424, 2007.

[9] S. Jamal, Deskripsi Penyakit Sistem Sirkulasi: Penyebab Kematian Utama di Indonesia, Cermin Dunia Kedokteran, 2004.

[10] World Health Organization (WHO), Occupational Health. World Health Organization, Geneva, 2000.10

[11] Wu, Y. Chi, Chen, C. Sung; Chan, and Y. Jiun. "The outbreak of COVID19: An overview," Journal of the Chinese Medical Association, vol. 83, no. 3, pp. 217-220, 2020.

[12] Y. T. Xiang, W. Li, Q. Zhang, Y. Jin, W. W. Rao, L. N. Zeng, G. K. I. Lok, I. H. I. Chow, T. Cheung, and B. J. Hall. "Timely research papers about COVID-19 in China," The Lancet, Vol. 395, no. 10225, pp. 684-685, 2020. 